\title{
Factors Influencing Cost Overruns in Construction Projects of International Contractors in Vietnam*
}

\author{
Thong Quoc VU' ${ }^{1}$ Cuong Phu PHAM${ }^{2}$, Thu Anh NGUYEN ${ }^{3}$, Phong Thanh NGUYEN, \\ Phuong Thanh PHAN ${ }^{5}$, Quyen Le Hoang Thuy To NGUYEN ${ }^{6}$
}

Received: July 03, 2020 Revised: July 28, 2020 Accepted: August 10, 2020

\begin{abstract}
A construction project is a designed product made up of labors, materials, and installations in the project positioned on the ground and may include the underground and ground section, and the section in water or on the water surface. It is a civil, industrial, transport, agricultural and rural development, infrastructure, or some other. A key phase in the life cycle of these construction projects is the implementation when building products are made directly with workers, equipment, materials, and managers. If there is a lack of management experience, information, and problem-solving solutions to tackle the risks faced by contractors, especially foreign ones, will fail in controlling the project's cost. This study was conducted with investigations, discussions, and evaluation of the factors that lead to cost overruns in the construction projects of international contractors in Vietnam. The principal component analysis (PCA) showed that those factors that influence cost overruns these construction projects fall into five general groups, including factors related to (i) the owners, (ii) the foreign contractors, (iii) the subcontractors and suppliers, (iv) state management, and (v) the project itself. Besides, the study proposes solutions to limit cost overruns in construction projects and improve the profitability of international contractors in Vietnam.
\end{abstract}

Keywords: Cost Overrun, Financial Management, Foreign Contractor, Project Management, International Management

JEL Classification Code: G39, F39, M16

\footnotetext{
*Acknowledgements:

This research is funded by University of Transport and Communications (UTC), Campus in Ho Chi Minh City, Vietnam. We acknowledge the support of time and facilities from Ho Chi Minh City University of Techonology (HCMUT), VNU-HCM for this study. We also would like to thank Mr. Anh N. T. for helping this research. The authors gratefully acknowledge Ho Chi Minh City Open University, Ho Chi Minh City, Vietnam, for supporting this research.

${ }^{1}$ First Author. Assistant Professor, Head, Accounting Information System Department, Faculty of Accounting and Auditing, Ho Chi Minh City Open University, Vietnam. Email: thong.vq@ou.edu.vn

${ }^{2}$ Assistant Professor, Dean, Faculty of Transport and Economics, University of Transport and Communications, Campus in Ho Chi Minh City, Vietnam. Email: ppcuong@utc2.edu.vn

${ }^{3}$ Assistant Professor, [1] BIM Lab Director, Ho Chi Minh City University of Technology (HCMUT), Vietnam. [2] Vietnam National University Ho Chi Minh City, Vietnam. [3] Ho Chi Minh City Open University, Vietnam. Email: nathu@hcmut.edu.vn

${ }^{4}$ Assistant Professor, Department of Project Management, Ho Chi Minh City Open University, Vietnam. Email: phong.nt@ou.edu.vn

${ }^{5}$ Lecturer, Department of Project Management, Ho Chi Minh City Open University, Vietnam. Email: phuong.pthanh@ou.edu.vn ${ }^{6}$ Corresponding Author. Assistant Professor, Deputy Director, Office of Cooperation and Research Management, Ho Chi Minh City Open University, Vietnam [Postal Address: 97, Vo Van Tan Street, District 3, Ho Chi Minh City, 724000, Vietnam]

Email: quyen.nlhtt@ou.edu.vn
}

\section{Introduction}

Globalization has brought significant foreign direct investment (FDI) to Vietnam over the past ten years (Nguyen \& Ngoc, 2020; Nguyen, Quan, Le, \& Van, 2020). Sixty to seventy percent of it has flowed into industrial and construction projects. This has attracted investors into the Vietnamese construction market. Many international contractors have become involved in major projects in Vietnam, such as the East-West Highway Construction Project (with a Japanese joint-venture contractor), Dung Quat Oil Refinery (with a French Contractor), My Thuan Bridge (with a Vietnamese and Australian joint-venture contractor), Can Tho Bridge (with a Japanese contractor), Ben Thanh-Suoi Tien Metro Line (with Japanese and Korean contractors), Season Avenue Complex, Hanoi (with a Chinese contractor), Water

\footnotetext{
(C) Copyright: The Author(s)
}

This is an Open Access article distributed under the terms of the Creative Commons Attribution Non-Commercial License (https://creativecommons.org/licenses/by-nc/4.0/) which permits unrestricted non-commercial use, distribution, and reproduction in any medium, provided the original work is properly cited. 
Surface-based City Project, Hai Phong (with a Japanese contractor), etc. (Vu, Vu, Wang, \& Min, 2018). Foreign direct investment in Vietnam has been attractive to foreign contractors, in large part, because foreign owners almost always rely on reputable and experienced foreign contractors with whom they have a relationship to invest and work abroad because of the overall size of the domestic contracting resources (Ha, Le, \& Trung-Kien, 2019; Nguyen, 2020; Nguyen \& Ngoc, 2020).

Despite the advantages, foreign contractors in Vietnam confront multiple difficulties, like cultural differences, lack of knowledge of geographical and weather conditions, lack of comprehensive understanding the work style of Vietnam's owners, subcontractors, and suppliers, in addition to factors out of their control, such as political stability, exchange rates, inflation, and others (Brahmasrene \& Lee, 2020; Lee \& Brahmasrene, 2019; Sy, Likhitruangsilp, Onishi, \& Nguyen, 2017). They are these factors that cause a project's failure, especially construction cost overruns and delayed schedules, which has been very common. Hence, for corporate sustainable development and projects' success, it is necessary to identify, analyze, and evaluate the influences factors that lead to construction cost overruns to ensure expenditures are within the budgets set forth by the foreign contractors.

\section{Literature Review}

Vietnamese construction law states that contractors are entities and individuals that are qualified to engage in construction activities and construction practice when participating in contractual relations in construction investment activities. At the same time, foreign contractors are foreign entities and individuals with civil legal capacity and, in case of individuals, with civil act capacity also, to sign and execute contracts (Huynh et al., 2019; Pham \& Hadikusumo, 2014). The civil legal capacity and civil act capacity of foreign contractors are determined following the laws of the countries of their nationality. Foreign contractors may be general contractors, main contractors, joint venture contractors, or subcontractors (Lee \& Park, 2017; Weiss, 2018). In other words, a foreign contractor means an entity incorporated under its country's laws or an individual with a foreign nationality participating in a bid in Vietnam.

Within a project, construction costs include direct costs, general costs, and taxable income before valueadded tax. They involve various items such as demolition costs, ground leveling costs, and costs for construction of works, work items, temporary works, and auxiliary ones. Costs are determined based on group quantities, types of construction work, structural units or construction parts, and the corresponding general construction price measured and calculated, and several other estimated relevant costs
(Bozgulova et al., 2019; Luong, Tran, \& Nguyen, 2018). The purposes of cost control are to monitor the formation of costs and expenditures during construction and provide solutions to ensure the construction costs are within the approved budget. Cost control is an ongoing process to limit construction costs within a budget, without cost overruns (Ramabodu \& Verster, 2013; Tu \& Giang, 2018).

A cost overrun means the excess of actual costs over the approved budget. It is frequent in infrastructure, construction, or engineering projects. Indeed, there have been many large projects conducted by foreign contractors in Vietnam that have experienced significant cost overruns. For example: (i) Can Tho Cable-Stayed Bridge project, with the longest main span in Southeast Asia, constructed by JV Contractor TaiseiKajima-Nippon Steel. In 2007, at the end of the bridge in Vinh Long province during the construction of two approach spans about 30 meters high between the three piers, an incident caused by the settlement of the temporary piers' foundation framework resulted in the repair, and cost up to VND 13 billion, incurred by the Japanese contractor and VND 34 billion from other sources; (ii) East-West Highway Project, constructed by Japanese Contractor Obayashi. The nonconforming surface aggregate causes land subsidence and pavement deformation in some areas, resulting in increased costs; and (iii) Keangnam Landmark Tower Project, Hanoi, constructed by Main Contractor Keangnam Enterprises, with three towers, consisting of two 48-story towers and one 70-story commercial tower, and an investment of over US\$ 1 billion. During the construction, several incidents caused overruns, such as a fire caused by unsatisfactory welding, and electrical connection or glass breakage due to steel cage shaking and impacting the glass surface on the $40^{\text {th }}-50^{\text {th }}$ floors while cleaning the glass.

The construction phase is the most crucial in these projects. It has a great influence on the construction costs incurred by contractors. Absence of management experience, necessary available information, and remedies are commonly experienced by contractors, in general, and foreign ones, in particular, cause construction costs to be out of control. Zhi (1995) received an insight into the risks of engaging in publicly-funded and private partnership-funding of construction projects abroad. His study highlighted ten risk factors for cost overruns: high inflation, the bureaucracy of local officials, project site security and order, corruption, bribery, engineer qualifications, lack of a means for transportation, interest rate fluctuations, absence of a legal system, and lack of means of communication. Fang, Li, Fong, and Shen (2004), in their study, identified risks in the construction market in China. They determined that out 44 risk factors affecting foreign contractors' performance of projects in China, unusual behavior of owners and the intervention of government authorities in the construction market were the most influential. 
A study by Memon, Rahman, Abdullah, and Azis (2010) identified essential influences on construction costs of large projects in Malaysia. Fifteen of the most important influences on project costs were proposed by project management consultants. Among them, the five factors that affect costs were (i) contractors' cash flow and financial difficulties; (ii) contractors' poor site management and supervision; (iii) inexperienced contractors; (iv) lack of site workers; and (v) inaccurate planning and schedules. Fidan, Dikmen, Tanyer, and Birgonul (2011) recognized that the risk of cost overruns in construction projects depended on the causal relationship between different risk sources. A database describing risk events in international construction projects and a cost overrun prediction model was built to simulate negotiations between project stakeholders on cost-sharing and consideration of contractual risk allocation terms.

Eybpoosh, Dikmen, and Birgonul (2011) surveyed 166 projects implemented by Turkish contractors on international mayors with SEM. The authors concluded that a causal relationship exists between 36 risk factors. Identifying these risks will help decision-makers track their effects throughout the project life cycle and provide solutions to limit risks. Meanwhile, Olaniran, Love, Edwards, Olatunji, and Matthews (2016) concluded that up to $64 \%$ of major projects around the world suffered from cost overruns. Factors such as the complexity of project characteristics, human resources, technology, structure, and culture, were generally found to result in cost overruns in hydrocarbon megaprojects. Nguyen and Nguyen (2020) analyzed 28 risks for design-build projects in Vietnam. The three most important were delays in project approval and licensing, interest rate fluctuations, and technical specification deficiency and change. Many studies have focused on project costs and risks; however, there has not been a study on cost overruns suffered by foreign contractors in Vietnam. This study, hence, aimed to identify and analyze the influences on cost overruns suffered by foreign contractors in Vietnam. It was designed to support both foreign and domestic contractors and project managers in establishing appropriate solutions to prevent or limit foreseeable cost damages (Phan, Nguyen, \& Nguyen, 2020).

\section{Research Methodology}

The research was conducted in four main steps:

(i) Step 1: Review articles and interview eight experts who have over ten years of experience in managing foreign contractors' costs to identify the main factors leading to cost overruns of foreign contractors in Vietnam. This step was to eliminate extraneous factors in the Vietnamese context and to group those with similar content and arrange related factors into a group. The first survey with experts was conducted to propose a preliminary questionnaire with 34 factors. (ii) Step 2: Develop a preliminary questionnaire and send it to experts and long-time experienced staff for feedback and correction; conduct trial interviews, and revise the questionnaire; finalize the official questionnaire with 31 factors.

(iii) Step 3: Conduct a formal survey by an interview in person, via email, or phone. Ninety-eight completed questionnaires were collected. Among them, 86 questionnaires were valid, accounting for $87 \%$. Cronbach's Alpha was used to assess the reliability, and principal component analysis (PCA) was carried out from the survey results to group the factors.

(iv) Step 4: From the analysis, conclusions were reached, and some solutions related to the research topic were proposed.

Principal component analysis (PCA) was applied to identify new uncorrelated variables to replace initial correlated variables, recognizing principal variables for use in multivariate analysis. Therefore, it is proper and acceptable to use the PCA technique to achieve the research objective of identifying influences on cost overruns in construction projects of foreign contractors and measuring the impact level of each factor.

\section{Results and Discussion}

Surveyed subjects were experienced individuals who had or were working for foreign contractors in different positions and on different types of projects in terms of project scale, funding sources, project types, and signed contract types. To evaluate the difference in means of factors by survey group, a Kruskal-Wallis test was done. This non-parametric test compared the difference in the means of a dependent variable by two or more independent variables without requiring the dependent variables to have a normal distribution. Based on 86 completed questionnaires with six information sections on the project scale - funding sources, project type, foreign contractor's country, surveyed individual's experience and surveyed individual's role - the analysis results showed that the sig coefficients of all factors were greater than 0.05 , demonstrating no difference in the assessment of the impact level on cost overruns in construction projects of foreign contractors among these groups. In particular, in terms of contract type, the significance of factor (Bureaucracy, corruption, and bribery of stakeholders) was less than 0.05 , requiring it to be verified by Bonferroni (a posthoc test). The results showed that significance coefficients of pairs of unit price contracts and lump-sum contracts, unit price contracts, and adjusted unit price contracts, and lump-sum contracts and adjusted unit price contracts were greater than 0.05 . The differences between these groups were quite small and not statistically significant. Therefore, the next research step could rely on the collected data. All 31 factors were identified, and the means were calculated, as shown in Table 1 below: 
Table 1: Ranking of influence factors on cost overruns in construction projects of international contractors

\begin{tabular}{|c|c|c|c|}
\hline $\mathrm{N}^{\circ}$ & Ranking of influence factors on cost overruns in construction projects of international contractors & Mean & Rank \\
\hline I & Contractor-related factors & & \\
\hline 1 & Unstable financial situation & 2.99 & 10 \\
\hline 2 & Limited experience of construction organization & 2.98 & 11 \\
\hline 3 & Loose management and poor supervision of quantities & 3.14 & 04 \\
\hline 4 & Loose management and poor supervision of quality and schedule & 2.70 & 25 \\
\hline 5 & Unguaranteed occupational safety & 2.71 & 24 \\
\hline 6 & Loose management of site material and machinery warehouses & 2.37 & 29 \\
\hline 7 & $\begin{array}{l}\text { Weak management of contracts with owners concerning increasing quantities and remedying of } \\
\text { the defect and unfavorable contractual terms for contractors }\end{array}$ & 3.07 & 06 \\
\hline 8 & Delay in the decision-making process of contractors & 2.69 & 26 \\
\hline 9 & Improper communications between contractors and subcontractors & 2.94 & 14 \\
\hline II & Owner and project manager-related factors & & \\
\hline 10 & Owners' payment delays & 3.00 & 09 \\
\hline 11 & Owners' poor qualifications & 2.97 & 12 \\
\hline 12 & Extension of the project implementation schedule & 3.49 & 01 \\
\hline 13 & Contract suspension or arbitrary contract cancellation & 3.19 & 03 \\
\hline 14 & Delayed and incomplete handover of the construction site & 3.12 & 05 \\
\hline 15 & Owners' deliberate presentation of incomplete quantities in bidding documents & 2.84 & 20 \\
\hline III & Designer-related factors & & \\
\hline 16 & Poor quality of design documents & 2.95 & 13 \\
\hline 17 & Delays in dealing with design changes & 2.67 & 27 \\
\hline 18 & $\begin{array}{l}\text { Adoption of different construction codes and standards from those ever applicable to foreign } \\
\text { contractors' projects in their countries }\end{array}$ & 2.35 & 31 \\
\hline IV & Engineer-related factors & & \\
\hline 19 & Poor qualifications of site engineers & 2.78 & 23 \\
\hline 20 & Untimely instructions and decisions on acceptance and approval of drawings and quantities & 2.80 & 21 \\
\hline V & Subcontractor and supplier-related factors & & \\
\hline 21 & Subcontractors' insufficient finance for construction & 2.79 & 22 \\
\hline 22 & Subcontractors' poor construction experience & 2.93 & 15 \\
\hline 23 & Supply of poor-quality materials and supply delays & 2.93 & 16 \\
\hline $\mathrm{VI}$ & Other influence factors & & \\
\hline 24 & Difficulties or delays in administrative authorities' approval and licensing process & 3.05 & 07 \\
\hline 25 & Legal document changes with impacts on projects & 3.01 & 08 \\
\hline 26 & Inflation or increased interest rates & 2.87 & 18 \\
\hline 27 & Abrupt increases in site worker demand & 3.26 & 02 \\
\hline 28 & Unclear and incomplete geological survey documents & 2.87 & 19 \\
\hline 29 & Bad weather conditions & 2.88 & 17 \\
\hline 30 & Differences in culture and working environments and language barriers & 2.36 & 30 \\
\hline 31 & Bureaucracy, corruption, and bribery of stakeholders & 2.60 & 28 \\
\hline
\end{tabular}


Based on the ranking of influence factors on cost overruns in construction projects of foreign contractors, the survey results showed that the five factors with the highest means included: (1) Extension of project implementation schedule (3.488); (2) Abrupt increases in site worker demand (3.256); (3) Contract suspension or arbitrary contract cancellation (3.186); (4) Contractors' loose management and poor supervision of quantities (3.140); and (5) Delayed and incomplete handover of the construction site (3.116). The fact that the factor of "Extension of project implementation schedule" ranked first because an extension of a project implementation schedules increases the construction costs. Owners may request the extensions of project implementation schedules for a variety of reasons such as the market situation, lack of or problems with funding sources, design problems, or construction site issues. Mostly, contract extensions were mostly attributed to contractors. However, foreign contractors cannot request that owners cover all costs arising from an extension of the construction schedules.

In most cases, owners attempt to blame delays on contractors to minimize the costs claimed by contractors. Owners only agree to pay a part of the costs for reasons such as sharing difficulties with owners and shortening the period of the extension at owners' fault in many ways such as increasing the difficulty level of acceptance or payment procedures, or imposing the staffing changes, or requiring the strict quality of documents without flexibility. Consequently, amounts collected from the owners may not be enough to cover the actual damages caused by the extensions. As a result, the construction costs incurred by contractors exceed their budgets and reserves, results in the loss of contractor profit because contractors must pay the additional costs of management and acquiring machines and equipment. In case there is an extension, construction unit prices may vary. In short, the "extension of project implementation schedule" is significant, which significantly affects the cost overruns of the foreign contractors (Long, Tran, \& Nguyen, 2019). The solutions for contractors, such as: (i) Before signing contracts, contractors need to carefully negotiate terms (FIDIC can be applied) on an owners' request for the extensions of project implementation schedules and corresponding compensation levels; (ii) In the construction phases, contractors should:

- Check how much impact the extensions of project implementation schedules have on contractors.

- Meet and make specific minutes with owners, and propose the potential requests of owners by tabulating payable costs resulting from extensions, such as those of management, renting machines and equipment, reassigning construction workers, loan interests, etc., and obtain verification for finalizing contract appendixes.
- Propose options to minimize the indirect costs to the lowest possible level, such as reducing resources for projects, transfer to other works, return machines and equipment to the lessors, sign principal contracts with subcontractors or suppliers to protect against slippage due to the extensions.

The factor of "abrupt increases in site worker demand" also affects construction cost overruns. The reason is that there has been a sharp increase in worker demand in the construction industry, which has resulted in scarcity, greatly affecting the overall management plan such as construction and handover schedules of foreign contractors. To meet the construction and handover schedules as planned, contractors must organize night shifts, allocate more supervision and safety staff, and adjust labor costs to ensure that the relevant duties are executed properly. Contractors cannot foresee these costs, and the provision for slippage of labor costs appropriated by foreign contractors is not enough to cover the profit loss. If contractors have not signed or negotiated price agreements with subcontractors, they must almost always incur these costs. The contractors should select qualified and experienced subcontractors who can ensure unintermittent construction without any interruption due to worker shortages. In addition, contractors need to request that subcontractors report the personnel situation daily (morning, noon, and evening), as well as warn subcontractors in the in case of shortage of construction personnel. Furthermore, contractors should also provide measures to support subcontractors, such as accommodations and travel costs for workers in the event of worker scarcity. Moreover, contractors should create a favorable working environment for workers with proper occupational safety, hygiene, rewards, etc. so that they feel assured during working in the project.

Besides, in most cases of contract suspension or arbitrary contract cancellation, both owners and contractors are influenced more or less. Although unexpected, it may happen for many reasons such as a legal problem, no construction permits being granted, no available connection agreements, an economic crisis due to an epidemic, the freezing of the real estate market, etc. or subjective reasons such as gradual handover of construction sites, unsound financial situations, etc. These all affect the construction plans of contractors for machines, equipment, workforce, and materials as well as financing and funding because the revenues from suspension or termination are insignificant compared to the amount spent for preparation by contractors. Therefore, this factor seriously affects foreign contractors and ranked third among the 31 influence factors for cost overruns. If contractors have not yet signed contracts, they should:

- Check legal documents of projects and construction sites before signing the contract. 
- Enquire about the financial situation of all the owners.

- Identify the condition of the real estate market (for civil works) and whether it is in good condition for signing contracts.

- Request owners include advance payment terms in contracts.

If contractors have signed contracts, they should:

- Hold emergency meetings with owners; tabulate the preliminary calculations of costs increasing in connection with damages caused by contract suspension or cancellation; request owners to confirm to minimize the damages incurred by contractors.

- Establish or hire legal consulting teams to handle these situations.

"Contractors' loose management and poor supervision of quantities" ranks fourth among the 31 factors. Construction quantity directly affects the construction costs of foreign contractors (Nguyen, Do, \& Nguyen, 2020). Indeed, quantity management is often proportional to cost management. Quantity management cannot be effective as expected for several reasons, such as having calculated insufficiently quantities, not understanding the nature of each specific task, which results in having the proposed unit prices, be inappropriate, failing to calculate quantities, executing tasks requested by owners beyond the contract, or not understanding subcontracts signed with subcontractors. This leads to foreign contractors having to pay the cost for remedying defects, or make warranty periods that favor of owners and are longer than those provided by subcontractors. Consequently, the result will be construction cost overruns by foreign contractors.

"Delayed and incomplete handover of the construction site" is one of the factors that have a significant impact on foreign contractors' construction cost overruns. For some construction projects that pass through many localities, such as roads or metro lines, or otherwise have not been subject to the comprehensive site clearance (since some households have not yet compensated satisfactorily for clearance), a partial handover of each construction site is preferred. However, in some cases, at the time of the commencement of construction, such locations cannot be cleared comprehensively. This affects the contractors' construction plans, resulting in a construction delay; it also adversely affects the construction plans that contractors signed with suppliers and subcontractors, and affects loans and increases interest expenses and indirect costs. Cost overruns will occur. Therefore, contractors should:

- Survey construction sites before signing contracts.

- Propose that owners include the specific plans for construction site handovers in the contracts.
- Keep track of the handover progress of owners to make appropriate preparation plans.

- Make minutes about the time of construction site handover as a basis for calculations of items that will be more costly in the future.

- Suspending or terminating contracts under the relevant contracts in cases where owners hand over construction sites more slowly than initially planned.

The scale reliability is measured and tested by Cronbach's Alpha coefficient to exclude the non-conforming variables before the PCA is carried out since these variables can create fake factors. Cronbach's alpha coefficient is $0.945>0.8$ calculated using SPSS software. This showed that the data of observed variables were suitable and had high reliability. During PCA, four factors were excluded in turn, because their factor loading was less than 0.5 . The results of PCA with varimax rotation for 24 factors are summarized and shown in Tables 2 and 3 below:

Based on an analysis of Table 3 , above, there are five main groups of influence factors on construction cost overruns by foreign contractors in Vietnam, which explains $71.2 \%$ of the problems in question. The authors discussed with some experts to assess in detail the impact of each influence factor, as follows:

\subsection{Owner-Related Factors}

This is a group of factors that greatly influenced the construction cost overruns by foreign contractors in Vietnam explained $42.5 \%$ of the problems in question. It reflects the fact that cost overruns by foreign contractors in Vietnam. They, who mostly general contractors, were a consequence of owners' faults such as owners' payment delays, owners' poor qualifications, extensions of project implementation schedules, contract suspensions, or arbitrary contract cancellations, delayed and incomplete handover of construction sites, and owners' deliberate presentation of incomplete quantities in bidding documents. Other factors were subject to the potential impacts of the faults of owners, such as design documents of poor quality, delays in dealing with design changes, unfavorable contractual terms for contractors, and unclear or incomplete geological survey documents.

Table 2: KMO and Bartlett's test results

\begin{tabular}{|c|c|c|}
\hline \multicolumn{3}{|c|}{ KMO and Bartlett's Test } \\
\hline \multicolumn{2}{|c|}{$\begin{array}{l}\text { Kaiser-Meyer-Olkin Measure of Sampling } \\
\text { Adequacy }\end{array}$} & .852 \\
\hline \multirow{3}{*}{$\begin{array}{l}\text { Bartlett's Test of } \\
\text { Sphericity }\end{array}$} & Approx. ChiSquare & 1473.835 \\
\hline & df & 276 \\
\hline & Sig. & 0.000 \\
\hline
\end{tabular}


Table 3: Summary of results of PCA with varimax rotation

\begin{tabular}{|l|l|l|l|c|}
\hline Code & Factors & Loading & Eigen value & $\begin{array}{c}\text { \% of } \\
\text { variance }\end{array}$ \\
\hline CDT & & & 10.202 & 42.509 \\
\hline & & .837 & & \\
\hline & & .814 & & \\
\hline & & .754 & & \\
\hline & & .743 & & \\
\hline & & .697 & & \\
\hline & & .625 & & \\
\hline & & .614 & & \\
\hline & & .612 & & \\
\hline & & .594 & & \\
\hline NT & & & 2.211 & 9.211 \\
\hline & & .854 & & \\
\hline & & .853 & & \\
\hline & & .782 & & \\
\hline & & .726 & & \\
\hline & & .703 & & \\
\hline TP & & & 2.115 & \\
\hline & & .790 & & \\
\hline & & .749 & & \\
\hline & & .628 & & \\
\hline & & .627 & & \\
\hline NN & & & 1.378 & \\
\hline & & .790 & & \\
\hline & & .731 & & \\
\hline & & .656 & & \\
\hline CT & & & 1.183 & \\
\hline & & .873 & & \\
\hline & & .809 & & \\
\hline & & & & \\
\hline & & & & \\
\hline & & & \\
\hline & & & \\
\hline & & & \\
\hline & & & \\
\hline & & & \\
\hline & & & \\
\hline & & & \\
\hline & & & \\
\hline & & & \\
\hline & & & \\
\hline & & & \\
\hline & & & \\
\hline & & & \\
\hline & & & \\
\hline & & & \\
\hline & & & \\
\hline & & & \\
\hline & & & \\
\hline & & & \\
\hline & & & \\
\hline & & & \\
\hline & & & \\
\hline & & & \\
\hline & & & \\
\hline & & & \\
\hline & & & \\
\hline & & & \\
\hline & & & \\
\hline
\end{tabular}

The deliberate presentation of incomplete quantities in the bidding documents: The quantities included in the bidding documents provided by owners often were less than those included in the bidding drawings. The failure of contractors to recheck carefully and to trust the quantities in signing lump-sum contracts generates cost damages. Thus, the actual value to be paid was often lower than the amount to be spent to complete their duties. Depending on the types of contracts that contractors signed with owners (lump-sum, fixed price, or adjustable price), contractors employed experienced and honest staffs to serve in the quality control departments, and, at the same time, coordinate with the technical departments to calculate the actual quantities to be executed in the future. For lump-sum contracts, contractors must report to owners on the quantity differences before signing the official contracts. When owners propose the execution quantities of items, contractors are required to recheck the quantities.

Delays in dealing with design changes: Owners were ineffective when dealing with design changes, resulting in much longer times for approval of design changes (Pham, Nguyen, Nguyen, \& Dinh, 2020). This influenced contractors' initial construction plans, created construction cost overruns and caused delays. In the case of owner delays in dealing with design changes, contractors should: (i) make records and request owners fix the delay periods as well as the costs of damages caused by the delays; (ii) coordinate to communicate regularly to urge owners to deal with design changes as soon as possible; and (iii) request owners sign working minutes in case a contractor must execute the work without an owner's response. Owners should pay contractors for any matters that arise.

Poor quality of design documents: Because owners often are ineffective, the quality of design documents presented are unsound. This affects the construction costs for contractors because contractors take a long time to prepare the shop drawings. Further, when contractors must wait for a response from owners, destruct the existing items to rework or repair also has a significant impact on the progress and construction costs and causes the passive state of contractors in the implementation of duties. To minimize the adverse influences from this factor, contractors need to: (i) check drawing carefully, prepare shop drawings in coordination with the departments, or use the building information model (BIM) to model the structures visually before implementation; (ii) make timely reports to owners and engineers on shortcomings or unclear details in the design drawings; (iii) regularly coordinate with and between related parties to speed up the handling of duties; (iv) record all solutions and report them to owners in case they influence construction costs so that owners can verify them to provide the basis for future payment of items that may arise.

Owners' payment delays: When owners delay payments, it affects the revenues of contractors, and, as a result, affect the plans for payments to subcontractors and suppliers. For smooth and uninterrupted execution of duties, contractors must mobilize funds from loans and pay additional interest expenses of the loans. If fund mobilization has to be repeated in the long run, it will adversely affect contractor budgets and cause cost overruns. So contractors should: (i) enquire about the owners' financial conditions before signing contracts requesting information from funding sources of the work and owners' previous partners; (ii) assess the general situation in the real estate market; (iii) request penalty terms 
for late payment in contracts be included in the contract; (iv) notify owners, in writing, of the late payment and penalty charges and request owners to make plans for payments to contractors; (v) propose that owners make payment guarantees; (vi) propose that the embassy of the foreign contractor's country assist (for ODA-funded projects); and (vii) At all times, prepare and set aside financial reserves for payment to subcontractors and suppliers in case of late payment by the owner.

Unclear and incomplete geological survey documents: The geological survey results of a current project are available, though some work finished long ago are not archived, have constantly changing complex geological situations, or are locally specific, but owners have not requested consultants to conduct thorough surveys or have selected less experienced consultants. When contractors must execute on a site with unverified geological surveys using construction methods that are not incompatible with the geology of the construction area, contractors often cannot foresee the risks of the construction process. In particular, contractors need to anticipate more costs to the project to handle these potential problems, which are greatest for underground construction that requires work underground and cannot be anticipated by contractors. For important projects or when having doubts about unfavorable geological conditions, contractors should re-survey the site. Contractors also need to survey adjacent structures that have been finished or are in progress to assess the geological conditions in the construction area preliminarily. In the case of their incompetence, contractors may hire competent design consultants to prepare and verify the construction methods for underground sections such as foundations or basements.

Owners' poor qualifications: The unqualified owners will often have design documents that are of poor quality, delay in dealing with design changes, and delay in obtaining permits related to legal procedures. This includes contractors' extensions of project implementation schedules. To meet the given schedule, contractors will have to implement their responsibilities even when the costs incurred are not approved; as a result, contractors will complete their duties before the approval is granted. However, the actual costs at the time of approval will be much higher than the prices approved by owners. Continuing a project before approval, therefore, may prevent an owner's poor qualification from causing construction cost overruns for the contractors. Contractors should assess owners' qualifications before signing contracts as well as agree with owners on some procedures and basic issues such as payment forms, payment time, quality document forms, etc. Also, contractors must regularly report on changes or delays that are the owner's fault and request that an owner confirm the issue.

Weak management of contracts by owners concerning increasing quantities, remedying of defects, and unfavorable contractual terms for contractors: This factor is directly related to contractors but is determined by owners. In case of problems that arise or defect that needs to be remedied, which owners confirm the insufficient quantities compared to the actual ones, it will cause the construction cost overruns of contractors. Contractors should study and negotiate construction contracts to ensure their rights. In particular, contractors should adopt the provisions of internationallyrecognized contracts such as the FIDIC. Moreover, contractors also need to employ divisions of experienced quantity management staff to regularly monitor the on-site variations in the original designs and request owners to confirm the matters that are the responsibility of the owners. On the other hand, contractors should also strengthen exchanges and built good relationships with owners.

\subsection{Foreign Contractor-Related Factors}

Foreign contractor-related factors explained 9.2\% of problems, including their limited experience with the construction organization, unstable financial situation, loose management and inadequate supervision of quantities, loose management, and poor supervision of quality and the schedule, and unguaranteed occupational safety.

Limited experience of the construction organization: With limited experience in construction organizations, contractors cannot forecast difficulties in the construction process, such as overlapping or non-methodological layout of construction sites, which causes low productivity. Contractors also may propose suboptimal construction methods, causing waste and influencing contractors' cost overruns.

Unstable financial situation: Financially, in addition to revenues from owners, contractors must also appropriate the available funds to make prompt payments to subcontractors and suppliers. Otherwise, the construction progress will be affected, prolonging the construction schedule, which becomes the justification for owners to impose penalties for delay and for subcontractors to cancel subcontracts. This causes cost overruns because to remedy this situation requires extra-costs.

Loose management and poor supervision of quantities: Including the missing or insufficient quantities in the contractual payment documents, as well as calculating the arising quantities of contractors with owners, or proposing unit prices lower than the market unit prices caused by the incomprehensive understanding of the constituent elements of unit prices, etc. result in owners paying less than costs for the actual construction quantities. Thus, the cost overruns of contractors are indispensable.

Loose management and poor supervision of quality and schedule: This results in substandard products, contractors must remedy many times, rework, and add labor. It substantially increases the contractors' material and labor costs. 
Unguaranteed occupational safety: Contractors' inability to manage and supervise occupational safety successfully, including working at heights, electrical safety, fire and explosions that result in construction accidents and injuries, such as the collapse of scaffolding or tower cranes, electric shocks, fires, and explosions, adversely impacts the health of the workers. Each one of them can disrupt the construction, and contractors must spend to overcoming the safety-related consequences, which often exceed contractors' reserves.

\subsection{Subcontractor-Related Factors}

Subcontractor- and supplier-related factors explained $8.8 \%$ of the problems in question, including subcontractors' insufficient funding for construction, subcontractors' lack of construction experience, lack of communications between contractors and subcontractors, and supply delays and supplying of poor-quality materials.

Subcontractors' insufficient resources for construction: Subcontractors' failures to pay wages and material costs promptly result in strikes or materials' ineligibility to meet timely the demands of duties, affecting the overall progress of construction. Therefore, the penalties for delay imposed by owners are likely while the penalties received from subcontractors are insufficient to offset those fixed by owners. Contractors should: (i) select subcontractors carefully before signing construction contracts; (ii) pay particular attention to their financial capacity and construction experience of the companies and individuals; (iii) closely monitoring the situation of subcontractors' workers on construction sites to assess accurately the current problems of subcontractors; (iv) check quantities frequently and make early payments to subcontractors who have cash-flow difficulties; (v) setting up payment procedures to ensure timely submissions by subcontractors and timely payments to those subcontractors, who can actively plan their financial issues.

Subcontractors' poor construction experience: Similar to that of contractors, the construction experience of subcontractors also significantly impacts cost overruns. For example, subcontractors may fail to set up a professional management system, appropriate construction procedures, and methods, or strict quality control. As a result, they take more time than planned and must overcome the problems caused by inexperience, often leading to cost-overruns, which adversely affect contractors' reputation, quality, as well as progress. Contractors should: (i) establish divisions for regularly supervising on-site construction activities; (ii) ensure good construction quality from the beginning to avoid inspection and repair after completion, which is very time-consuming and costly; (iii) request subcontractors submit statements for approval of construction methods as well as shop drawings of each duty before execution; (iv) impose sanctions on subcontractors who regularly affect the quality and progress of construction; (v) set out the constraints on specific responsibilities and obligations of subcontractors in contracts; and (vi) propose preventives measures in cases where subcontractors are unable to continue their execution.

Improper communications between contractors and subcontractors: Communication plays a vital role in project management (Pham et al., 2019). The process of performing duties involves accurate information about project design and progress. Accordingly, communication is necessary between stakeholders, the main contractors, and subcontractors. If the information provided is not accurate, complete, and timely, it may result in construction defects and failure to meet the given requirements. This affects the progress as well as the quality of duties executed by subcontractors. If contractors fail to provide adequate information, they will be responsible for compensation to subcontractors. Contractors should: (i) request the provision of having information provided through specialized departments so that the exchange of information is consistent, official, and clear; (ii) imperatively ask project managers or directors to attend weekly and monthly meetings to report on construction status, discuss difficulties and problems during the construction process as well as request the assistance for subcontractors; (iii) Subcontractors must be responsible for notifying contractors of any changes or deficiencies in the drawings so that they may be resolved as soon as possible to prevent the adverse impact on construction progress; (iv) encrypt names of the stored information so that the two parties agree on how to read the document names; (v) setting up procedures to respond to the inquiries of subcontractors.

Supply of poor-quality materials and supply delays: Contractors are entitled to claim against suppliers for indemnification for damages such as re-supplying materials following the quality that was guaranteed and for expenses incurred due to the provision of substandard materials such as paying the labor costs for dismantlement and reworking. However, suppliers' indemnification portions are limited to the value portions of contracts concluded between contractors and suppliers (Nguyen et al., 2018). This directly affects the reputation and construction progress of contractors in favor of owners. The consequences may be much more severe than the penalties imposed. Contractors should: (i) establish procedures for the selection and approval of material samples used for construction; (ii) check plants and workshops of material manufacturers; (iii) check whether the capacities of the suppliers allow them to meet the construction schedule; (iv) appoint officers to control the material manufacture procedures - from input materials to finished products - delivered to construction sites, including concrete piles, concrete poles, concrete culverts, etc.; (v) For large projects, establish material quality control divisions at the construction site for testing concrete, steel, sand, stone, etc.; (vi) immediately remove the inappropriate materials from 
construction areas to prevent their misuse; and (vii) set out the constraints on responsibility and warranty terms for suppliers.

\subsection{State Management-Related Factors}

State management-related factors explained $5.7 \%$ of the problems. These mainly include difficulties or delays in administrative authorities' approval and licensing processes, inflation or increased interest rates, and changes to the legal documents that have an impact on projects.

Difficulties or delays in administrative authorities' approval and licensing processes: Owners or contractors face overlapping and difficulties in obtaining permits such as permits for construction, connection, and handover of power systems and fire protection systems, etc. Due to problems unforeseen by contractors, the time for obtaining permits may be prolonged while expenses are increasing sharply, but the expected results cannot be achieved. This will affect the construction progress of contractors, resulting in adjustments to the project schedule according to the actual situation. For example, if the "extension of time" is the owners' fault, this factor will affect the indirect costs of contractors. Contractors should: (i) hire local consultants to ensure the preparation of correct and complete documents as required by local authorities; (ii) sign contracts with experienced and reputable subcontractors who are in contact with local authorities so that they are in charge of legal procedures; (iii) suggest local authorities respond according to pre-determined appointment schedules; and (iv) requesting the assistance of embassies, the World Bank or the Asian Development Bank to cause the government agencies to speed up the document review and approval progress.

Inflation or increased interest rates: Inflation stems from the increase in the price of goods. Accordingly, loan interest increases according to the adjustment and management of the state. These two issues directly and adversely affect construction costs. It means that contractors must spend more money than initially planned. Contractors should: (i) look at statistics on the situation of labor wages and material prices in the market to make forecasts before offering a bid price as well as for the phases of project implementation; (ii) sign principal contracts with suppliers to ensure that price change only insignificantly during the process of project implementation; (iii) sign lump-sum or fixed-price contracts with subcontractors; (iv) request owners adjust unit prices for the arising items; (v) speed up the progress of completion of work; (vi) negotiate and supplement the terms on the slippage of labor and material prices; and (vii) sign fixed interest rate principal contracts with banks

Legal document changes that impact projects: Foreign contractors in Vietnam engage in the implementation of a significant number of projects for a long time (many years). During such periods, the State and its agencies may issue decrees, circulars, and decisions in the field of construction, such as those on State management, health insurance policy, social insurance, and accident insurance, etc. These affect the projects that are being constructed by contractors. Accordingly, construction costs are probable to be higher than initially planned by contractors. Contractors should: (i) subscribe to risk and insurance policies for damages caused by laws, decrees, and circulars (Phong, Likhitruangsilp, \& Onishi, 2017; Sy, Likhitruangsilp, Onishi, \& Nguyen, 2017); (ii) negotiate with owners the contractual terms regarding changes in laws, circulars, decrees, and proposing the extensions of time and cost increases that favor the contractor.

\section{Conclusions}

This research has focused on 31 factors divided into five main groups that often lead to construction cost overruns for foreign contractors in Vietnam. These refer to the groups of owner-related issues, foreign contractor-related issues, subcontractor-related issues, state management-related issues, and project-related issues. It is a useful reference for foreign as well as domestic contractors so that they can anticipate problems and propose appropriate solutions that limit cost overruns. Although foreign contractors are experienced and use the modern technology of construction, have sound financials, and internationally standardized management systems, there are still many country-specific problems that result in the cost overruns, and Vietnam is no exception. Some general recommendations for international contractors are as follows: (i) select ODA-funded projects to ensure payment by the government; (ii) form joint ventures with reputable contractors in Vietnam to take advantage of their strengths, such as stable finance and technology of foreign contractors in addition to workers, prestige, and relationships of Vietnamese contractors; (iii) sign contracts with owners based on international standards (such as FIDIC) to ensure legitimate benefits in the handling of payments, raising quantities, progress, and inflation; (iv) build good relationships with owners and local authorities to help favorably solve difficulties and problems for contractors; (v) search for and selecting experienced subcontractors and suppliers in Vietnam and build good relationships with local contractors; (vi) promptly notify the various parties of difficulties and problems to be solved; (vii) maintain a professional working environment at all times to meet the set schedule of completion of the works; and (viii) select and build teams of highly qualified Vietnamese who can handle work effectively, and design the training programs to assess the actual capability of employees. 


\section{References}

Bozgulova, N., Parmanova, R., Abenova, M., Ivanyuk, T., \& Aryshev, V. (2019). Calculation methods for cost management in the construction industry. Entrepreneurship and Sustainability Issues, 7(2), 1450-1461. https://doi.org/10.9770/ jesi.2019.7.2(46)

Brahmasrene, T., \& Lee, J. W. (2020). Exchange rate movements and structural break on china fdi inflows. Contemporary Economics, 14(2), 112-126. https://doi.org/10.5709/ce.18979254.335

Eybpoosh, M., Dikmen, I., \& Birgonul, M. T. (2011). Identification of risk paths in international construction projects using structural equation modeling. Journal of Construction Engineering and Management, 137(12), 1164-1175. https://doi. org/10.1061/(ASCE)CO.1943-7862.0000382

Fang, D., Li, M., Fong, P. S. W., \& Shen, L. (2004). Risks in chinese construction market - contractors' perspective. Journal of Construction Engineering and Management, 130(6), 853-861. https://doi.org/10.1061/(ASCE)0733-9364(2004)130:6(853)

Fidan, G., Dikmen, I., Tanyer, A. M., \& Birgonul, M. T. (2011). Ontology for relating risk and vulnerability to cost overrun in international projects. Journal of Computing in Civil Engineering, 25(4), 302-315. https://doi.org/10.1061/(ASCE) CP.1943-5487.0000090

Ha, N. M., Le, N. D., \& Trung-Kien, P. (2019). The impact of urbanization on income inequality: A study in vietnam. Journal of Risk and Financial Management, 12(3), 14. https://doi. org/10.3390/jrfm12030146

Ha, N. M., \& Ngoc, B. H. (2020). Revisiting the relationship between energy consumption and economic growth nexus in vietnam: New evidence by asymmetric ardl cointegration. Applied Economics Letters, 1-7. [In Press]. https://doi.org/10.1 080/13504851.2020.1789543

Huynh, V. D. B., Nguyen, P. T., Nguyen, T. A., Nguyen, Q., \& Nguyen, T. T. H. (2019). Identifying the key competitiveness indicators for construction contractors. International Journal of Advanced and Applied Sciences, 6(4), 59-64. https://doi. org/10.21833/ijaas.2019.04.007

Lee, J. W., \& Brahmasrene, T. (2019). Long-run and shortrun causality from exchange rates to the korea composite stock price index. Journal of Asian Finance, Economics and Business, 6(2), 257-267. https://doi.org/10.13106/jafeb.2019. vol6.no2.257

Lee, K. T., \& Park, S. B. (2017). The effects of sla on service quality level and service productivity of sub-contractor. Journal of Distribution Science, 15(5), 65-73. https://doi.org/10.15722/ jds.15.5.201705.65

Long, L. D., Tran, D. H., \& Nguyen, P. T. (2019). Hybrid multiple objective evolutionary algorithms for optimising multi-mode time, cost and risk trade-off problem. International Journal of Computer Applications in Technology, 60(3), 203-214. https:// doi.org/10.1504/IJCAT.2019.100299
Luong, D. L., Tran, D. H., \& Nguyen, P. T. (2018). Optimizing multi-mode time-cost-quality trade-off of construction project using opposition multiple objective difference evolution. International Journal of Construction Management. [Online First]. https://doi.org/10.1080/15623599.2018.1526630

Memon, A. H., Rahman, I. A., Abdullah, M. R., \& Azis, A. A. A. (2010). Factors affecting construction cost in mara large construction project: Perspective of project management consultant. International Journal of Sustainable Construction Engineering and Technology, 1(2), 41-54.

Nguyen, H. H. (2020). Impact of foreign direct investment and international trade on economic growth: Empirical study in vietnam. Journal of Asian Finance, Economics and Business, 7(3), 323-331. https://doi.org/10.13106/jafeb.2020.vol7. no3.323

Nguyen, H. M., \& Ngoc, B. H. (2020). Energy consumption economic growth nexus in vietnam: An ardl approach with a structural break. Journal of Asian Finance, Economics and Business, 7(1), 101-110. https://doi.org/10.13106/jafeb.2020. vol7.no1.101

Nguyen, H. M., Quan, B. Q. M., Le, H. V., \& Van Tran, T. (2020). Determinants of intra-industry trade between vietnam and countries in tpp. Journal of Asian Finance, Economics and Business, 7(1), 123-129. https://doi.org/10.13106/jafeb.2020. vol7.no1.123

Nguyen, P., \& Nguyen, P. (2020). Risk management in engineering and construction: A case study in design-build projects in vietnam. Engineering, Technology \& Applied Science Research, 10(1), 5237-5241.

Nguyen, P. T., Nguyen, V. N., Pham, L. H., Nguyen, T. A., Nguyen, Q. L. H. T. T., \& Huynh, V. D. B. (2018). Application of supply chain management in construction industry. Advances in Science and Technology Research Journal, 12(2),11-19. https://doi.org/10.12913/22998624/92112

Nguyen, T. A., Do, S. T., \& Nguyen, P. T. (2020). Application of building information modeling (bim) in volume management of construction projects. Journal of Advanced Research in Dynamical and Control Systems, 12(2), 1845-1852. https://doi. org/10.5373/JARDCS/V12I2/S20201228

Olaniran, O. J., Love, P. E. D., Edwards, D., Olatunji, O. A., \& Matthews, J. (2016). Cost overruns in hydrocarbon megaprojects: A critical review and implications for research. Project Management Journal, 46(6), 126-138. https://doi. org/10.1002/pmj.21556

Pham, C. P., Nguyen, P. T., Nguyen, T. A., \& Dinh, H. T. T. (2020). Project change management using building information modeling 360 docs. International Journal of Advanced Science and Technology, 29(4 Special Issue), 1348-1357.

Pham, L. H., \& Hadikusumo, H. (2014). Schedule delays in engineering, procurement, and construction petrochemical projects in vietnam: A qualitative research study. International Journal of Energy Sector Management, 8(1), 3-26. https://doi. org/10.1108/IJESM-06-2013-0009 
Pham, V. Q., Nguyen, B. K. Q., Van Tu, B., Pham, H. T. T., \& Le, T. Q. (2019). Critical success factors of project management: The case of construction related projects in vietnam. Journal of Asian Finance, Economics and Business, 6(2), 223-230. https:// doi.org/10.13106/jafeb.2019.vol6.no2.223

Phan, P. T., Nguyen, P. T., \& Nguyen, L. T. (2020). Project manager selection using the evaluation based on distance from average solution approach. International Journal of Disaster Recovery and Business Continuity, 11(1), 364-372.

Phong, N. T., Likhitruangsilp, V., \& Onishi, M. (2017). Developing a stochastic traffic volume prediction model for public-private partnership projects. In: AIP Conference Proceedings 1903. 060010 (2017). https://doi.org/10.1063/1.5011564

Ramabodu, M. S., \& Verster, J. J. P. (2013). Factors that influence cost overruns in south african public sector mega-projects. International Journal of Project Organisation and Management, 5(1-2), 48-56. https://doi.org/10.1504/IJPOM.2013.053153

Sy, D. T., Likhitruangsilp, V., Onishi, M., \& Nguyen, P. T. (2017). Different perceptions of concern factors for strategic investment of the private sector in public-private partnership transportation projects. ASEAN Engineering Journal, 7(2), 66-86.
Sy, D. T., Likhitruangsilp, V., Onishi, M., \& Nguyen, P. T. (2017). Impacts of risk factors on the performance of public-private partnership transportation projects in vietnam. ASEAN Engineering Journal, 7(2), 30-52.

Tu, M. T. C., \& Giang, H. T. T. (2018). Estimating the impact of trade cost on export: A case study vietnam. Journal of Asian Finance, Economics and Business, 5(3), 43-50. https://doi. org/10.13106/jafeb.2018.vol5.no3.43

Vu, H. A., Vu, C. C., Wang, J., \& Min, L. (2018). Evaluating impacts of financial risks on schedule delays of international highway projects in vietnam using structural equation model. International Journal of Performability Engineering, 14(2), 363-375. https://doi.org/10.23940/ijpe.18.02.p18.363375

Weiss, M. (2018). State vs. Market in india: How (not) to integrate foreign contractors in the domestic defense-industrial sector. Comparative Strategy, 37(4), 286-298. https://doi.org/10.1080/ 01495933.2018.1497323

Zhi, H. (1995). Risk management for overseas construction projects. International Journal of Project Management, 13(4), 231-237. https://doi.org/10.1016/0263-7863(95)00015-I 